\title{
The Colombian Media Industry on the Digital Social Consumption Agenda in Times of COVID-19
}

\author{
Andrés Barrios-Rubio 1,2
}

Citation: Barrios-Rubio, A. The Colombian Media Industry on the Digital Social Consumption Agenda in Times of COVID-19. Information 2022, 13, 11. https://doi.org/ $10.3390 /$ info13010011

Academic Editor: Norbert Fuhr

Received: 5 November 2021

Accepted: 25 December 2021

Published: 28 December 2021

Publisher's Note: MDPI stays neutral with regard to jurisdictional claims in published maps and institutional affiliations.

Copyright: (C) 2021 by the author. Licensee MDPI, Basel, Switzerland. This article is an open access article distributed under the terms and conditions of the Creative Commons Attribution (CC BY) license (https:// creativecommons.org/licenses/by/ $4.0 /)$.
1 Faculty of Communication and Arts, Antonio de Nebrija University, Hoyo de Manzanares, 28240 Madrid, Spain; barriosr_andres@javeriana.edu.co

2 Department of Communication, Pontifical Javeriana University, Bogota 56710, Colombia

\begin{abstract}
The pandemic and lockdown forced the media and its agents to transform and think differently. The situation brought with it the reinvention of productive routines and revitalized the information consumption agenda of audiences immersed in screen devices. The operational change of the Colombian media industry, at a time of conjuncture, is approached by this research from a mixed, quantitative and qualitative methodology, with the aim of evaluating the response of the national news company to citizens' news expectations during lockdown. The case study outlines a digital characterization of the public's relationship with the media and communication. The corpus of analysis is made up of the actions of the main news agencies in Colombia-press (2), radio (5), television (2) - and their actions on social media-Facebook, Instagram, Twitter, YouTube-in the period between 1 January and 31 May 2020. The result of this study denotes a mediamorphosis of analogue media that revitalizes and integrates them into a $360^{\circ}$ consumption chain, focusing on content that gives way to a creative culture that adapts to the demands of the market and imposes a see now, share now strategy to expand its market penetration.
\end{abstract}

Keywords: COVID-19; virus; pandemic; isolation; media; web-media; app-media; media ecosystem; social networks; information company

\section{Introduction}

Lockdown reconsidered the concept of society and the role of the subject in the interaction with the collective, an alteration of needs that directly transformed the relationship of the audience with the media [1] and showed new consumption habits [2]. The craving for information revitalized the role of the press, radio and television in the media ecosystem, a strategic plan of action that linked the web and, especially, social media in a way that fostered a convergence of media and platforms in which new languages were assimilated [3]. The overabundance of information during SARS-CoV-2 renewed the schemes of production [4], content distribution [5] and the traditional business model of the media industry [6] meeting the presence of the public on portable screen devices-Smartphone, Tablets, iPod, MP3, MP4, among others [7,8].

In the digital environment, the audience breaks the verticality of the communication process and takes center stage with the ability to produce communicative content such as prosumers [9], subject to the possibility of starting a conversation with news producers and, in addition, participating in the content production process [10]. The communicative paradigm is transformed by technology, but it still follows patterns defined by the sender, in the control of messages, either in the conventional broadcast system or on social media profiles [11]. The media diet is made up of multimedia communication products-text, audio, video - that focus, regardless of time, space or connection mode, on synchronous or asynchronous consumption in which the public personalizes their content menu $[12,13]$.

The design of the consumption route addresses action, visualization and interpretation logics that are linked to the dynamics of access to the communication proposal on an 

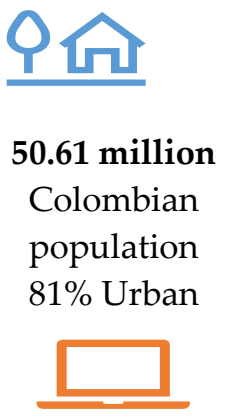

9H $10 \mathrm{M}$

Daily use of the Internet interactive screen with resources, such as the inclusion of links or links between texts, graphics, video sequences, sound, animations and even music, which are interconnected and hierarchical among themselves [14]. The innovation phenomenon that impacts the global media industry makes it interesting to stop at markets defined a priori by centers of interest or by geographic areas, as is the case in this study; research focus group that allows for the analysis of the dynamics of content production [15] and thus the assessment of its implications in a given media ecosystem. The informative synergy of conventional media, web-media and media with @ Facebook, Twitter, Instagram, YouTube [3] where business conglomerates, owners of traditional media-press, radio, television-are committed to establishing a communication pool from which to standardize their content agenda [4].

The media transformation functionally and operationally altered the mass media [16] to face the explosion of digital followers [17] and continue to serve as the axis of social construction [18], a relationship that has its base of action in what Martínez-Costa [19] and Orozco-Gómez [20] call the transmedia narrative supported by the cross-media expansion of the product. The subject generates many edges in the field of communication research and in the Colombian context it calls special attention to the important connection of the population with the digital ecosystem, technological devices, and the time of use and consumption (Figure 1). The penetration of ICT in the national market denotes the need for the media industry to design an operating strategy, in order to broaden its horizons of action while reconfiguring and reinventing itself to compete on equal terms with the productive dynamics of the new media [21,22].
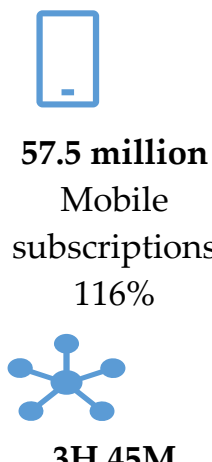

$3 \mathrm{H} 45 \mathrm{M}$

Social media

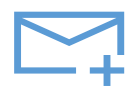

34 million

Internet users

$68 \%$

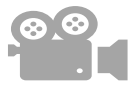

3H 30M

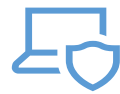

34 million

Active users in

social networks $68 \%$

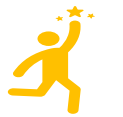

1H 24M

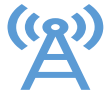

31 million

Social network $62 \%$

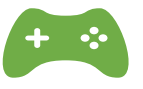

0H 53M users from mobile

Figure 1. Penetration of the digital ecosystem in Colombia. Source: Prepared by author with Hootsuite data [23].

The mobile scene of contact and social interaction (Figure 1) is heightened by the formation of digital communities [24]; a spiral of interconnection in which followers are constituted in micro-networks of action and establish a particular dynamic distribution and reception of communication content [25]. The audience as a transition axis in the reception acts under a communication model that breaks the traditional unidirectionality of the mass media [26]. On social platforms (Figure 2) the expectations of the sender and the audience converge [27] and this leads to a reinvention in the way we act [28]; a multiplicity of proposals that outlines a competition for content, it fights for relevance and prominence, without forgetting quality [29].

The operational tactic of the information industry is based on the technical and cultural knowledge of the user [30]. It seeks to ensure maximum connection and communicative effectiveness concentrated on the Smartphone; an instrument that connects the media and its products with users. Functional reengineering $[2,4]$ that meets the expectations of the modern audience and makes the brand of the medium visible as a reference for consultation and consumption. Coexistence of conventional and virtual dynamics of the press, radio 
and television that do not ignore the great mass, but do focus on the specific niches of users that cling to a network, app, or platform in the digital ecosystem.

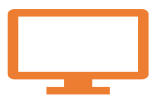

$99 \%$

Watch online

Videos

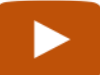

$98 \%$

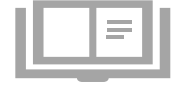

$49 \%$

Read blogs

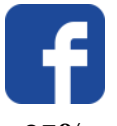

95\%

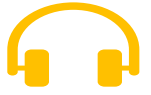

64\%

Listen to music and streaming services

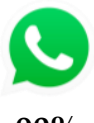

$90 \%$

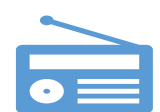

$57 \%$

Listen to online radio

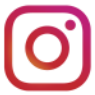

$70 \%$

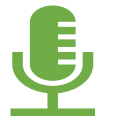

$36 \%$

Listen to podcast

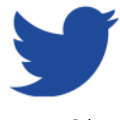

$55 \%$

Figure 2. Presence of Colombians on social networks and content they consume on the network. Source: Prepared by author with Hootsuite data [23].

Social platforms bring together communities with new space-time coordinates that define the virtual environment through technology to have the world in the palm of your hand. The communicative framework requires a culturalization and digital appropriation on the part of the mass media for the potential use of user accessibility to the communication proposal from different devices [31]. The market is saturated with technological artifacts that are used by fans eager for relationships and recognition [32], the need for attention that is evidenced in social networks and virtual groups, and how said public interacts with the media and journalists in the digital environment [33].

Isolation impacted the way of life of citizens, transformed the social and cultural interaction of subjects with their group through technology. The structure of society reflects a challenge in the media ecosystem for content producers and their relationship with users [4]; a new dynamic in the consumption of communicative products by the audience, which imposes on the media the design of innovative strategies to capture the public's attention [34]. Adaptation to the needs and habits of the population where traditional media converge with new media to regain presence, in the agenda of use and appropriation of information, within the framework of a novel media ecology [16]. This research focuses its attention on the response of Colombian news agents to the demand for news events by the contemporary viewer in a lockdown environment. The axis of study focuses on two specific questions on which the analysis is articulated:

I1. How is communication managed by issuing and receiving agents on social platforms in the midst of the lockdown?

I2. What is the narrative axis, point of interest, of the Colombian media-press, radio and television - to reach the attention of the users and structure the vision of a particular topic?

The pandemic and lockdown created a communicative habitat in which mediation [35] increases competition in such a way that the ways of seeing and assimilating the social context are expanded. The evolution of the media industry denotes a process in which it is reinvented and rearranged to a sequence that begins and becomes a trend on social platforms, develops on the web, radio and television to be widely analyzed in the press the following day [36]. The flow of messages in the digital ecosystem denotes a redundancy effect of the message that in a subtle way leads the public to execute a projected consumption action, a technique that implies structuring an integrated communications plan in which the potential of each medium and its penetration into the social fabric are exploited.

\section{Methodology}

The corpus of observation was selected taking as a reference the General Media StudyEGM- [37] which points out the informative approach of Colombians to the traditional 
mass media-newspapers (39.6\%), radio (74.4\%), television $(76.7 \%)$-and their proposals on digital channels-social networks (54\%), instant messaging applications (38.5\%), streaming on digital platforms (35.2\%), web-medium or app-medium $(28.7 \%)$, mail $(17.8 \%)$, SMS text message (13.5\%) [38]. The sample selection criterion is intrinsically linked to the consumption of national $(70.3 \%)$, international $(56.3 \%)$ or local/regional $(56.1 \%)$ news by the population through: the two national newspapers (El Tiempo and El Espectador), the five generalist radio stations that cover the country (Caracol radio, $\mathrm{W}$ radio, Blu radio, $\mathrm{RCN}$ radio and the FM) and the two newscasts of the private television channels (Noticias Caracol and Noticias RCN). Given that it is intended to establish the conduct of the media industry and its operating tactics in confinement, the information was systematized by industry - press, radio, television-and not by business brand.

During the SARS-CoV-2 pandemic, Colombians were kept informed through the traditional media news on the Internet; a digital setting where each user spent an average of $79.6 \mathrm{~min}$ becoming informed. Video was the resource that captured people's attention on the Internet (67.1 min per person), while the traditional media that was preferred by the people is the radio to which Colombians dedicated to listening on the Internet, 1,527,690,000 min, just considering the top 10 sites dedicated to providing this service [38]. The informative guide reveals a content production for the consumption of cultural practices, in which the traditional media industry and its presence on digital platforms converge (Table 1) as an effort to reactivate the consumption of informative content that is produced by the traditional company. A change in audience attitudes that transforms as the pandemic progresses, identification of a new user that leads mass media to transform their productive routines and adapt to change to guarantee the continuity of their presence in the Colombian media ecosystem, with the alteration that this implies for their business model.

Table 1. Media and its users (31 May 2020).

\begin{tabular}{ccccc}
\hline MEDIA/SOCIAL NETWORK & FACEBOOK & TWITTER & INSTAGRAM & YOUTUBE \\
\hline Press & $10,043,189$ & $12,308,523$ & $3,008,185$ & $1,059,000$ \\
\hline Radio & $6,061,656$ & $15,861,052$ & $2,381,894$ & 703,300 \\
\hline Television & $8,800,747$ & $16,667,417$ & $3,660,846$ & $3,570,000$ \\
\hline
\end{tabular}

From the given scheme of the Colombian digital biosphere, this research outlined a case study [39], which constituted a virtual sketch [40] that outlines, considers, and characterizes the relationship of the media industry and its audience on social platforms [41,42]. The data set (Table 2) is made up of the messages on Facebook - taken directly from the profiles on this social network —and Twitter-obtained through the Twitonomy platform-images on Instagram - downloaded from the profiles of each medium on study days-and videos on YouTube-graphic record from the profile on the social platform-subject of the media-user interaction between 1 January and 31 May 2020.

Table 2. Corpus of study downloaded from social profiles.

\begin{tabular}{ccccc}
\hline MEDIA/SOCIAL NETWORK & FACEBOOK & TWITTER & INSTAGRAM & YOUTUBE \\
\hline Press & 26,654 & 59,448 & 2338 & 2780 \\
\hline Radio & 60,360 & 142,735 & 2015 & 2190 \\
\hline Television & 22,466 & 42,144 & 958 & 5898 \\
\hline
\end{tabular}

Source: Prepared by the author.

The quantitative research input was processed in validated observation files $[43,44]$ in a preliminary way with the coders, in an effort to guarantee the correct and uniform interpretation of the data [45] and subtract possible hermeneutical deviations [46]. The 
tables were made up of three sections: activity-behavior flow of each profile, publications on social platforms, content-type of publication in relation to the activity it purposes, and media-user-product relationship-interaction promoted by published messages. The quantitative data sample (Table 2) provides statistical elements of frequency that were analyzed under the analysis categories detailed in Table 3.

Table 3. Quantitative data analysis categories.

\begin{tabular}{|c|c|c|c|c|}
\hline PLATFORM & CORPUS & CATEGORY & DEFINITION & $\begin{array}{l}\text { CRITERIA OF } \\
\text { ANALYSIS }\end{array}$ \\
\hline \multirow[t]{2}{*}{ FACEBOOK/TWITTER } & \multirow{2}{*}{$\begin{array}{l}36,632 \text { posts / } \\
79,343 \text { tweets }\end{array}$} & $\begin{array}{l}\text { Management of } \\
\text { issuing agent }\end{array}$ & $\begin{array}{l}\text { Industry tactical } \\
\text { operation to impact } \\
\text { followers on } \\
\text { social networks }\end{array}$ & $\begin{array}{l}\text { Means of communicating } \\
\text { to maintain contact and } \\
\text { share information [47]. } \\
\text { The media and its influence } \\
\text { on the construction of } \\
\text { public opinion [48]. }\end{array}$ \\
\hline & & $\begin{array}{l}\text { Management of the } \\
\text { receiving agent }\end{array}$ & $\begin{array}{l}\text { Reply, acceptance or } \\
\text { propagation of the } \\
\text { communicative proposal } \\
\text { of by the receiver on the } \\
\text { social network }\end{array}$ & $\begin{array}{l}\text { Media consumption by the } \\
\text { audience and participation } \\
\text { in the content [49]. } \\
\text { Coexistence of off and } \\
\text { on-line [33]. }\end{array}$ \\
\hline \multirow[t]{2}{*}{$\begin{array}{l}\text { INSTAGRAM/ } \\
\text { YOUTUBE }\end{array}$} & \multirow[t]{2}{*}{$\begin{array}{l}2051 \text { images / } \\
4777 \text { videos }\end{array}$} & $\begin{array}{c}\text { Visual and } \\
\text { narrative strategy }\end{array}$ & $\begin{array}{l}\text { Graphic structure, } \\
\text { publication periodicity, } \\
\text { semiotic instruments that } \\
\text { are used in the } \\
\text { communicative structure. }\end{array}$ & $\begin{array}{c}\text { Evolutionary } \\
\text { transformation of the } \\
\text { environment [50]. } \\
\text { Preparation of the medium } \\
\text { to face the challenge of the } \\
\text { audience's digital } \\
\text { environment [51]. }\end{array}$ \\
\hline & & Communication process & $\begin{array}{c}\text { Thematic offer, } \\
\text { correlations of visual } \\
\text { composition, } \\
\text { photographic sequences } \\
\text { and hypermedia links. }\end{array}$ & $\begin{array}{l}\text { Multiplatform synergies } \\
\text { [52]. } \\
\text { New journalistic panorama } \\
\text { [53]. }\end{array}$ \\
\hline
\end{tabular}

Source: Prepared by the authors.

Second phase of the research process concentrated the actions on the qualitative analysis of the messages, reflective observation of the content that is denoted in the publications [54,55]. The corpus of study characterizes the phenomenon [56] from the actions indicated in observed text-written and visual $[57,58]$. The approach to the content of the communications (Urchaga, 2009) started in an objective and systematic way from elements for the crossing of categories (Table 4) that delineate the behavior and strategy of the sender [57]. The convergence of textual and visual codes made it possible to sketch and execute the research from which certainties, interpretations and deductions emerged [59]. Triangulation of information that answers the questions with which the research started and opens new avenues of inquiry for future work.

Table 4. Quantitative analysis categories used in performance analysis on social networks.

\begin{tabular}{cc}
\hline VARIABLE & DESCRIPTOR \\
\hline Scenario mapping & Tactic that opts for a $360^{\circ}$ user consumption \\
\hline Communicative proposal & $\begin{array}{c}\text { Written, sound and visual narrative axis in } \\
\text { the message }\end{array}$ \\
\hline Media-user interaction & $\begin{array}{c}\text { Relationship between attention and propagation of } \\
\text { the message }\end{array}$ \\
\hline
\end{tabular}


The media-user digital socialization [60] makes use of new channels [61] to revitalize the connection of the media-press, radio and television-with its audience; 5-month follow-up-January, February, March, April and May-that shows the operational strategy of the Colombian media industry in the social isolation phase. The balance of the ecosystem that establishes a model of attraction and participation in the multiplicity of offers that attack the user's attention from the development of the Internet and mobile devices that bring with them the convergence of five key factors in the digital environment [62]: media industry, technological context, content, professionals and users.

\section{Results}

\subsection{Communication Management on Social Platforms}

Photographs of research momentum denote, in the study period, the effort of the sending agent to achieve key figures of percentage growth in the number of followers (Table 5). Communication activity in the digital scene is related to the impact of the virus worldwide-February - the quarantine in Colombia-March and April, and the boredom of thematic unification concentrated on SARS-CoV-2 (deaths, infected, recovered, projections of peaks, global and local spread, bureaucratic egos, economic crisis, unemployment, among others)-May. The need for information in the social collective heightens the search for news in the traditional media, in its analogical and digital proposals, by the recipients: deep analysis-written journalism-permanent updating-sound story and real personification-visual narration. Communication between the medium and its users in the midst of lockdown reveals the importance of brand positioning and the reflection of trust and credibility that, by family tradition, is held in a particular medium.

Table 5. Percentage growth of followers in the study period.

\begin{tabular}{ccccccc}
\hline Network & Medium & January & February & March & April & May \\
\hline \multirow{3}{*}{ Facebook } & Press & $0.91 \%$ & $24.84 \%$ & $1.02 \%$ & $0.96 \%$ & $0.37 \%$ \\
\cline { 2 - 6 } & Radio & $0.85 \%$ & $0.69 \%$ & $1.39 \%$ & $1.63 \%$ & $1.24 \%$ \\
\cline { 2 - 6 } & Television & $0.64 \%$ & $0.86 \%$ & $2.05 \%$ & $1.75 \%$ & $0.76 \%$ \\
\hline \multirow{3}{*}{ Twitter } & Press & $0.57 \%$ & $0.51 \%$ & $1.58 \%$ & $0.97 \%$ & $0.37 \%$ \\
\cline { 2 - 7 } & Radio & $0.73 \%$ & $0.73 \%$ & $2.12 \%$ & $1.32 \%$ & $0.70 \%$ \\
\cline { 2 - 6 } Instagram & Television & $0.29 \%$ & $0.33 \%$ & $1.05 \%$ & $0.79 \%$ & $0.41 \%$ \\
\cline { 2 - 6 } & Press & $3.55 \%$ & $2.50 \%$ & $7.81 \%$ & $4.76 \%$ & $2.07 \%$ \\
\cline { 2 - 6 } & Radio & $2.71 \%$ & $3.04 \%$ & $11.65 \%$ & $7.19 \%$ & $3.86 \%$ \\
\hline \multirow{3}{*}{ YouTube } & Television & $3.25 \%$ & $2.85 \%$ & $8.11 \%$ & $6.61 \%$ & $4.21 \%$ \\
\cline { 2 - 6 } & Press & $10.40 \%$ & $6.52 \%$ & $13.90 \%$ & $9.04 \%$ & $6.18 \%$ \\
\cline { 2 - 6 } & Radio & $6.61 \%$ & $4.62 \%$ & $7.29 \%$ & $6.91 \%$ & $5.53 \%$ \\
\hline Source: Prepa $\%$ & $7.45 \%$ & $7.02 \%$ & $4.34 \%$ \\
\hline
\end{tabular}

Source: Prepared by the author.

The corpus of study warns that there are increasingly more active users (Table 5) who are on the hunt for specific topics on different platforms, the news content proposed by the mass media-global 17\%, national $71 \%$ and local $12 \%$ captures them in the middle of the situation and loyalty to a platform. Analysis of the material under investigation shows a significant number of thematic followers, infoweb [63], who follow precise topics on social networks, up-to-the-minute data that portray what is happening in the world and the local environment (Figure 3). During their screen time, users face the impact of events and content through a multiplicity of messages (Table 2); an expressive universe, which forms the construction of the collective imagination and is translated into psychological reality and vision of the near world. Tactical operation of the broadcasters, on social platforms, warns of the attraction of audiences through audiovisual content, communication products 
with a high number of impressions-press 8,007,745, radio 956,893, television 20,344,578, a trend that reflects the chaos of the social fabric.

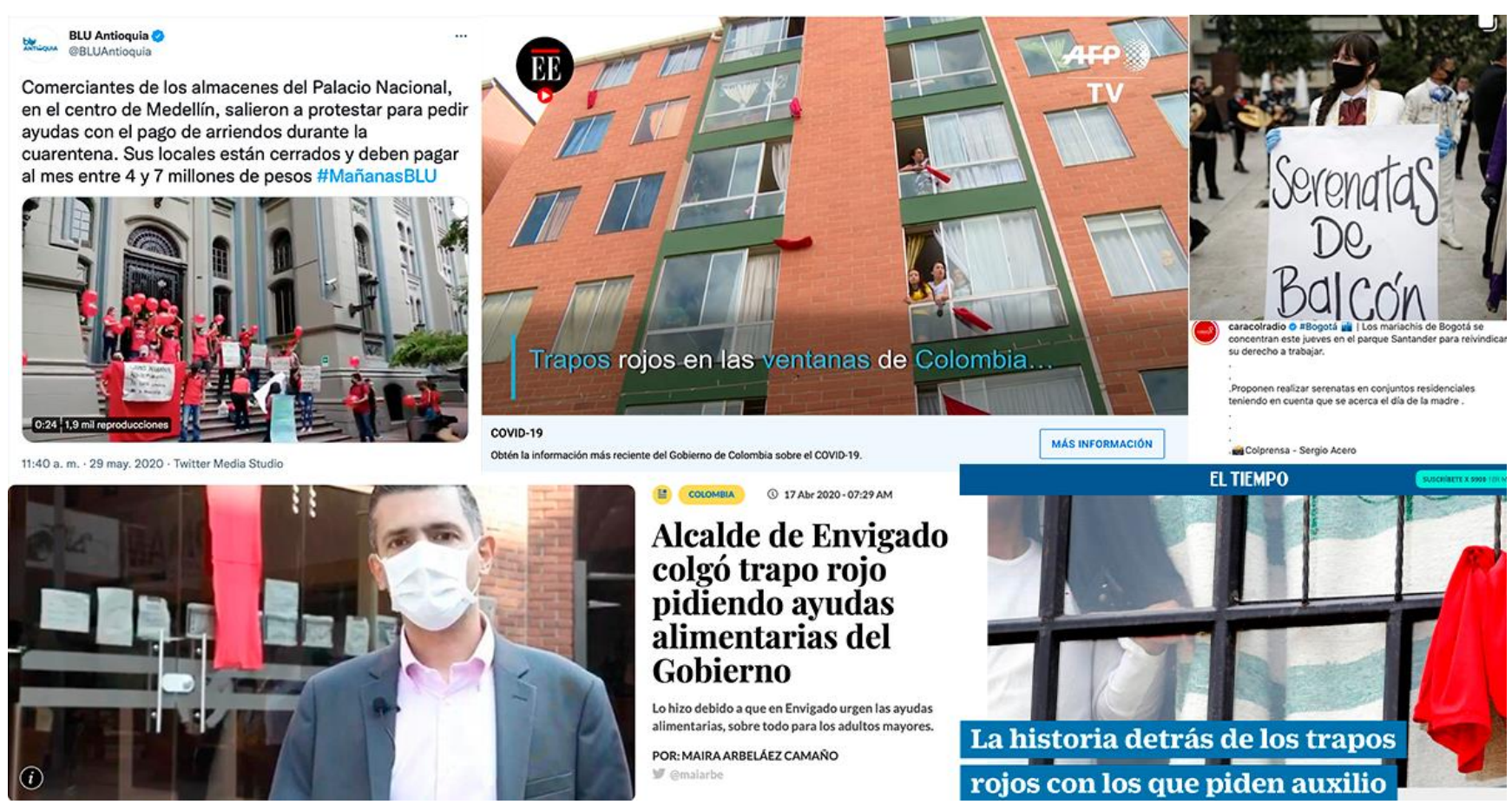

Figure 3. Messages issued in the study period. Source: prepared by the author with images extracted from digital platforms.

The information company's operating strategy (Figure 3) reveals the creation of attractive content for the receiver from a convergence of striking headlines, impressive textual advances and images or videos that portray what is happening. The media establish a daily broadcasting matrix - press (Facebook 176, Instagram 16, Twitter 390, YouTube 18), radio (Facebook 395, Instagram 10, Twitter 940, YouTube 15), television (Facebook 148, Instagram 6, Twitter 278, YouTube 40) (Average number of daily messages published by the media in the study period) - and control day-to-day printing and news with communicative content that nourishes the web-media and media profiles on social platforms from a constant update. The information traffic seen on social platforms awakens the sensitivity of written text supported by video - press $(76 \%)$, radio $(35 \%)$, television $(96 \%)$, images — press $(22 \%)$, radio $(54 \%)$, television $(4 \%)$-and links - press $(81 \%)$, radio $(93 \%)$, television $(81 \%)$, that strategically activate $360^{\circ}$ consumption through each of the platforms on which the communication media is present. The compilation of the study material allows us to affirm that $37 \%$ of the information is new and $63 \%$ is the repetition of what has already been said in previous hours; minimal modifications of the text that updates the news or refreshes the impact of the events on the user's initial screenshot.

Focusing attention on the audiovisual component, it is important to review a media activity focused on the Facebook Live tool to attract public attention -608 publications in the press, 550 on radio and 684 on television (Average monthly messages published by the media in the period of study). It is an important action strategy that generates direct interactions with the follower-1,556,426 in the press, 470,990 on radio and 2,728,130 on television - which denotes that the visual component has gained relevance on mobile screens. Regarding the percentage of users who share Facebook Live publications with their followers, the difference is very slight between the media-press (29\%), radio (32\%), television $(31 \%)$ - despite the divergent flow in the volume of interactions. The moving image is the center of action for the consumption of media content through the Smartphone. The analysis confirms that YouTube is an important content repository with a significant 
number of stored videos (Table 2), although greater importance reflects the number of playbacks it achieves-344,220 in the case of newspapers, 276,345 in the case of radios and 274,016 television channels. The evidence allows us to heighten the important work of printed media to regain presence in the consumption agenda of users, digital relevance that places them in the focus of the conversation.

Informational leadership of the media brand establishes a stable and lasting relationship with the follower who, from their social account, expresses a series of comments and reactions -like or share- about the medium's messages (Table 6); a response that drives communication between users and encourages a telephone game in which the person talks and never receives a stimulus from the sender. Public participation is notably increased in the Live broadcasts that are transmitted to develop the events: press-Facebook 9,069,288, Instagram 3,945,150, Twitter 791,804, YouTube 259,446-, radio -Facebook 6,539,615, Instagram 285,215, Twitter 813,670, YouTube 137,250, television -Facebook 7,267,890, Instagram 968,180 , Twitter 678,478, YouTube 597,900 (average monthly reactions to Live used by the media in the period of study). As can be seen in Table 6, the reaction connection is related to the peaks of the epidemiological phenomenon in the country. A scenario of interest that in the first months-January and February-focuses on sharing information, in the stage of strict isolation-March and April-has a high percentage of activity (86\%) in comments and personal particularization of the situation, and the last stage-May-reflects tiredness with the situation with derogatory attitudes that border on rudeness. Triangulation of factors that denotes a strong connection between the media and followers in the months of March and April, but which has a shock in May that calls for a rethinking of the focus and structure of the messages so as not to wear down the link achieved by the virus.

Table 6. Response rate to messages sent in the period of study.

\begin{tabular}{ccccccc}
\hline Network & Medium & January & February & March & April & May \\
\hline \multirow{3}{*}{ Facebook } & Press & $6,797,796$ & $8,317,788$ & $13,393,900$ & $8,817,982$ & $8,018,978$ \\
\cline { 2 - 6 } & Radio & $5,564,250$ & $6,460,540$ & $9,481,165$ & $4,403,345$ & $6,788,770$ \\
\cline { 2 - 6 } & Television & $6,213,024$ & $7,147,642$ & $9,878,022$ & $6,078,884$ & $7,021,880$ \\
\hline \multirow{3}{*}{ Twitter } & Press & 603,958 & 666,544 & 921,794 & 993,070 & 773,650 \\
\cline { 2 - 6 } & Radio & 577,500 & 546,715 & 966,020 & $1,109,790$ & 868,320 \\
\cline { 2 - 6 } & Television & 446,892 & 461,018 & 871,694 & 932,270 & 680,512 \\
\hline \multirow{3}{*}{ Instagram } & Press & $3,069,740$ & $3,644,104$ & $4,944,506$ & $4,451,580$ & $3,615,818$ \\
\cline { 2 - 6 } & Radio & 128,035 & 125,420 & 347,265 & 417,140 & 408,225 \\
\cline { 2 - 6 } & Television & 478,442 & 541,226 & $1,199,088$ & $1,573,028$ & $1,049,114$ \\
\hline \multirow{2}{*}{ YouTube } & Press & 262,880 & 210,436 & 356,562 & 285,148 & 182,206 \\
\cline { 2 - 6 } & Radio & 135,620 & 109,835 & 163,210 & 170,845 & 106,745 \\
\cline { 2 - 6 } & Television & 482,060 & 639,270 & 706,316 & 668,490 & 493,364 \\
\hline
\end{tabular}

Source: prepared by the author.

Data in Table 6 confirm a greater concentration and involvement of the public with the analyzed newspapers, whose publications managed to generate almost twice as many reactions during the research period as those of television channels and more than three times those of radio stations. The media-user relationship is implicit in the reactions to the messages (Figure 4). The study corpus allows us to observe the images and messages, grouping the manifestations of the audience into six emotional categories previously established by the researchers: attraction-press (20\%), radio (17\%), television (18\%), amazement-press (10\%), radio (12\%), television (16\%), fun-press (19\%), radio (26\%), television $(10 \%)$, sadness - press $(22 \%)$, radio $(19 \%)$, television $(28 \%)$, anger-press $(27 \%)$, radio $(25 \%)$, television $(25 \%)$, other-press $(2 \%)$, radio $(1 \%)$, television $(3 \%)$. The public follows the media on the social platform because they feel an affinity to the mass media 
and their work, but they do not always approve of the facts, characters and actions that they become aware of in the communication. The reaction index is closely linked to the fifth power people have on social networks, empowerment to do things, establish alliances and reconfigure the role of the user before the sender. The ability to notify, listen and respond shows empathy between members of the same culture who are identified with the reality that is broadcast by the medium.

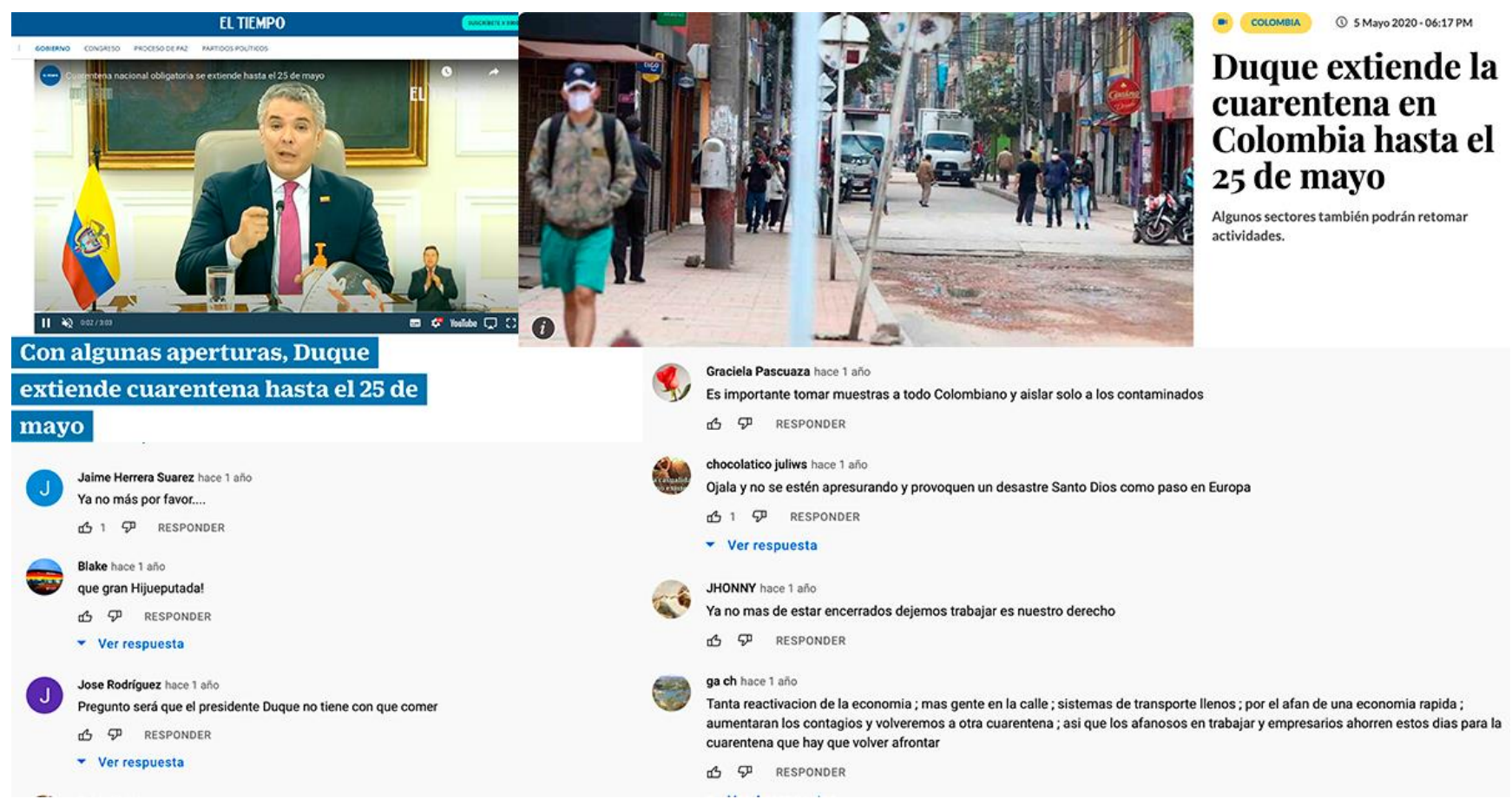

Figure 4. Short-term messages and user reaction. Source: prepared by the author with images extracted from digital platforms.

Social platforms are constituted in a scenario of the follower's commitment to the media account-press (17\%), radio (6\%), television (15\%)—which activates the defense of the subject's opinions before others, conversation from fans-press (4\%), radio (13\%), television (3\%)-who seek to be heard and provide arguments that they hope will be taken into account. Co-creation of content related to the editorial line of the medium, judgment and vision of the deeds that delineates the reality present in the conscious and unconscious of the collective imagination. Penetration capacity that demonstrates the effectiveness of the strategy configured by the media industry based on the performance index of their profiles on digital platforms - press (31\%), radio (23\%), television (27\%).

\subsection{Narrative Axis and Points of Interest in Social Conversation}

The media ecosystem is constituted in a spiral of convergence; a space in which users obtain news from social networks-38\%, web-media-34\%, search engines-19\%, conventional media-9\%. In [37], a data bank where the facts are known and last over time so that everyone can enter, use or consult them. The qualitative analysis of this study, observation of the messages and their narrative structure (Figure 5), indicates that the media have fallen into a phenomenon in which they want to communicate everything, the social performance of telling and becoming part of the trends of conversation through a tag code that, in this particular situation, focused on: \#COVID19-20\%-, \#COVID_19-18\%, \#Coronavirus-18\%, \#COVID-19-12\%, \#Reporte-9\%-, \#yomequedoencasa-5\%, \#quedateencasa-5\%, \#preve nciónyacción-4\%, \#Colombia-3\%, \#COVID-2\%-, others-4\%. 

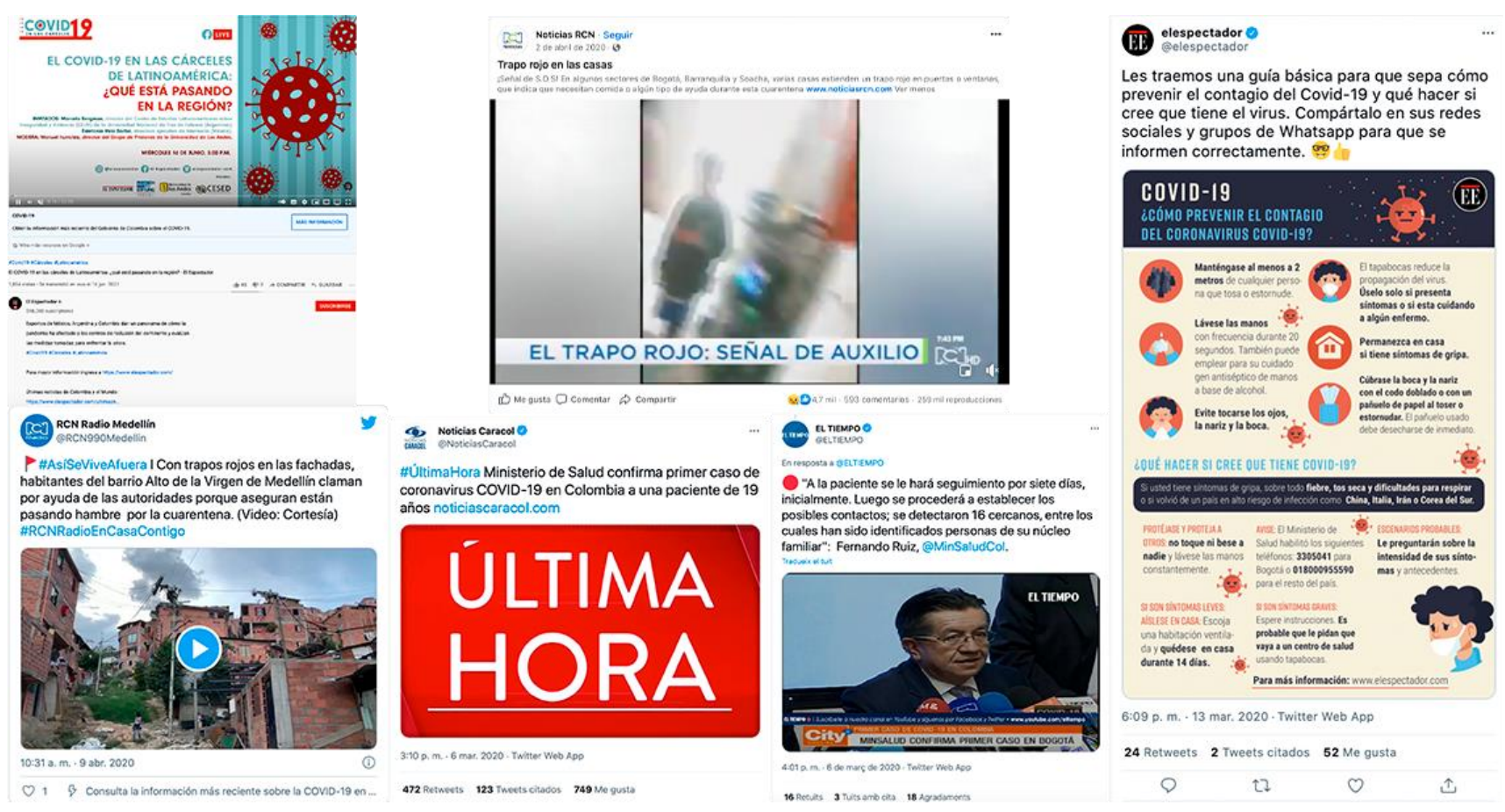

Figure 5. Examples of messages on social networks. Prepared by the author with images taken from social networks.

Construction of the messages by the issuing agent (Figure 5) considers the dynamics of consumption through Smartphone screens. The Colombian media ecosystem, in its digital proposals, points towards generational renewal and the more social nature of audiences. A challenge becomes evident that imposes a productive strategy to design and structure specific messages for the web, social networks and broadcasts in audio and visual streaming through clear and attractive headlines, short texts and expressive elements-images, videos, infographics, graphics, gifs-that help users to become interested and go deeper on the proposed topics. In general, the corpus of study denotes a timid effort by the Colombian media to adapt to the conditions of digital windows. It is not only about satisfying the users' centers of interest but, above all, focusing them from narrative strategies that, in addition to helping the critical interpretation of the reality that is read, heard or seen, manages to capture their attention above the exponential overexposure of stimuli provided by the Internet.

The qualitative analysis of the corpus of study shows that a high percentage $(78 \%)$ of the videos distributed on networks by the Colombian media respond to a simple treatment in visual performance and composition-plans, montage, sound or labels (Figure 6). More than a lack of specific equipment or technological tools, it is presumed that the production times of content for social networks are accelerated, and the logic of quantity and variety tends to prevail over that of the quality of the messages. In fact, publications on Twitter or Facebook quite often consist of the replica of the synchronous contents of the conventional medium, summaries of the product without any adaptation or personalization. Triangulation of the publications in the study period shows that the Colombian media-press, radio and television - tend to resort to similar data, approaches and topics, without fully assuming the mutation of consumer habits. At a high percentage $(90 \%)$, the content of the analyzed messages is produced from Bogotá, the capital of the Republic of Colombia. The review of the corpus of study shows that there are few messages originating from the regions and that they are replicated by the official account of the medium. We perceive how the production rooms, especially in the press, seem more concerned with capturing the 
attention of an urban audience that, however, shows stagnation rates and even a decrease in media penetration measurements.

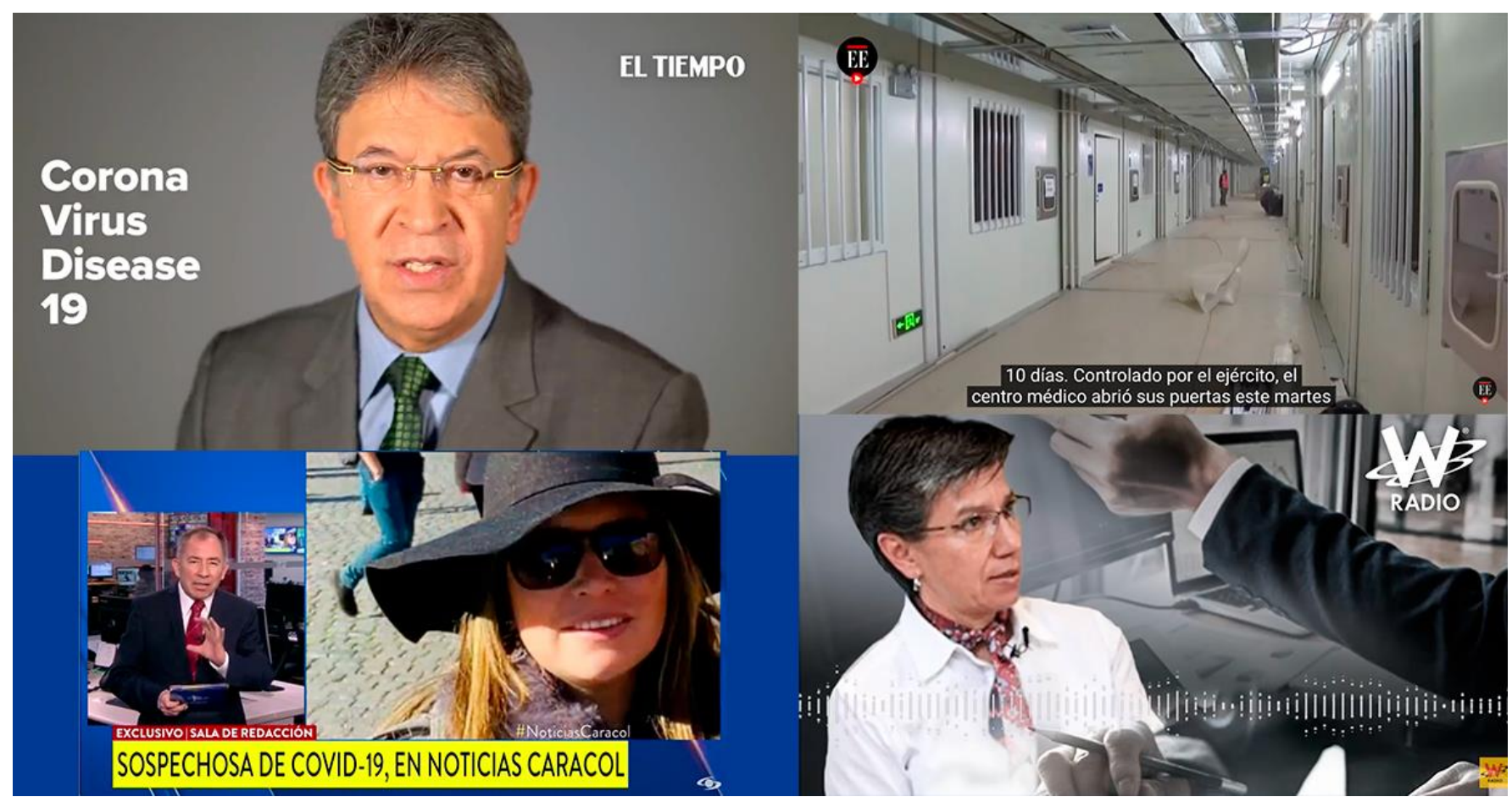

Figure 6. Composition of the audiovisual message on networks. Prepared by the author with images taken from social networks.

The qualitative analysis of the messages allows us to affirm that, in general, the press, radio and television strive to position the business brand of each medium on the digital scene so that the user perceives in it the credibility attributes achieved in the analogical environment. The analyzed messages combine short and suggestive texts that try to seduce the user along with videos, photographic galleries or sound capsules usually tagged with the social trends of the day or hashtag (\#). The navigation coordinates typical of crossmedia narratives help the relevance of the content to be reinforced by its formal presentation. It also appeals to the participation of users through "likes", comments or interactions with other recipients; a strategy of promotion, engagement, expansion and positioning clearly aligned with the needs and expectations of the millennial generation. The set of messages broadcasted by the main Colombian publishers on their social media profiles reveals a compelling and unquestionable fact: these media brands are being extended and reinforced both in devices and in time, and their content, with a margin of improvement. They show, however, an increasing effort to know the public and to reinvent the aesthetics and adaptation of their languages.

A combination of semantic and visual codes in the messages allows us to notice an effort by the news agency to adapt to an environment of action, an extension of the senses that transforms the perception of the world and from which it interacts on social platforms and communication instruments. The effort to assimilate social settings such as Facebook, Twitter, Instagram, YouTube, to keep the audience's attention, leads the media to create alternative spaces that accompany the social message: live, IGT, audio websites, podcasts and audio blogs (Figure 7). The study corpus reveals a symbiosis of new communication models from divergent ways of narrating data, facts, ideas and opinions from instantaneity, bidirectionality, multidirectionality, interactivity, hypertextuality and participation. The alteration of the relationship between existing technologies, industries, markets, genders, and audiences; operating logic that projects content to be processed by the audience from information and entertainment. 


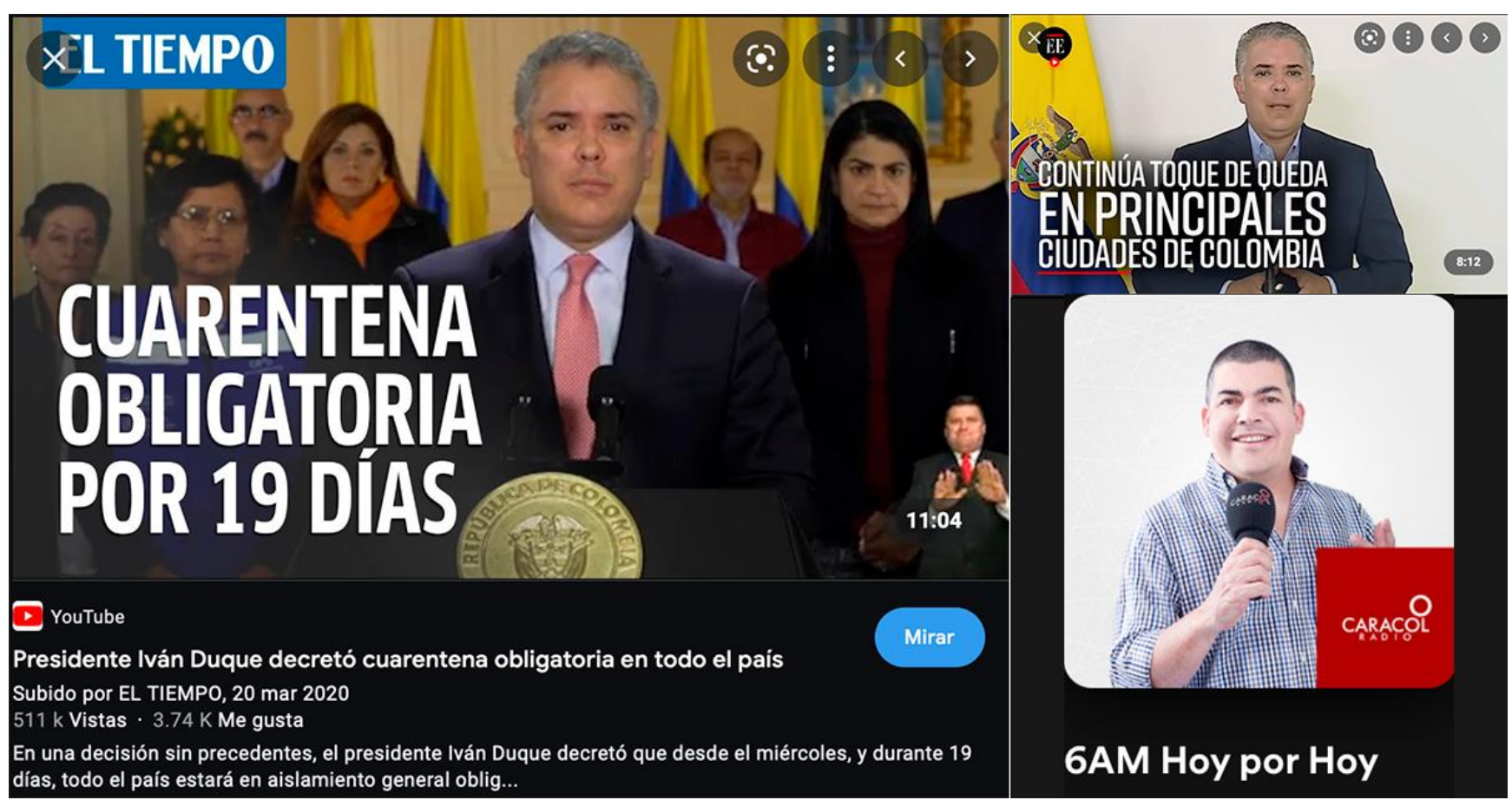

Figure 7. Appropriation of alternative broadcast scenarios by the media. Prepared by the author with images taken from social networks.

The atomization of information that surrounded the media sphere in the lockdown contrasts the news $(43 \%)$, the interviews $(24 \%)$, the opinion segments $(26 \%)$ and the special report $(7 \%)$ as courses to be highlighted in the messages. The information diet contains international events (17\%), local events, Bogotá as the epicenter of national politics, $(71 \%)$ and regional elements $(12 \%)$. The observation of the material demonstrated the spread or repeat of Fake news: taking methanol is a treatment or a cure against the virus; coronavirus is a mix of HIV, tuberculosis and malaria; there is already a vaccine against the disease; COVID-19 comes from a laboratory, it is a weapon of biological warfare between great powers; China asked a court to approve the sacrifice of 20,000 coronavirus patients; among others. The Colombian media in the framework of the pandemic revitalized the value of newsworthiness, constantly presenting content related to issues of poverty, mental health, domestic violence, therapeutic care, cases of infection, deaths, vulnerable population, seniors at risk, malnutrition, local and international outbreaks, number of cases, public health, possible cures, celebrities infected, and food shortages.

An analysis of the material collected for the research allows us to see a standardized tactic of the media in their messages on social platforms, a format that combines headlines, highlights interviews, and opinions, and includes the relevant events of the day: infected and deceased, and the health and financial situation. The web-media constitute the epicenter where the industry's content meets with the audience. Observation of the sample makes it possible to show that, during the period of study, the mass media, focused their informative agenda on the economic situation of the people and national and international companies, remote working, rotating work shifts, virtual school and university education, social isolation, public health, poverty, the opportunity to rethink finances and de-escalation of confinement. The communication proposal concentrates the flows of action by bands as follows: morning $(63 \%)$, evening $(15 \%)$ and night $(12 \%)$. The content of the messages reveals the scarce use of infographics to accurately and clearly synthesize important information, the writing uses concise language and short sentences. It is worth noting the constant use of adjectives such as "mortal" disease, "a silent enemy". The media are striving to attract more listeners who click through. For this they use the @ of social platforms, hashtags, hypertextuality and multimedia on the internet; without exception 
the following were found in the study corpus: campaigns on hygiene, temperature taking, hand washing, family life, donations, among others.

\section{Analysis}

\subsection{Information as a Roadmap of the Media-User Relationship}

The need for entertainment and information, knowing the other and what is happening around us, directly impacted the agenda of media consumption by users in the mandatory lockdown stage due to SARS-CoV-2. Apathy to the traditional content proposals of the mass media, indicated by other studies [64], was transformed with the presence of subjects at home. In accordance with what was stated by Aleixandre-Benavent, et al. [21], in the midst of the lockdown, the press, radio and television reflect an increase in the average hours of public consumption, a strategic triangulation is clear for meeting with the audience from the alternatives offline and on-line. During the lockdown, the media opted to fulfill the functions of company, distraction and fun while broadcasting the latest news, a range of content that responds to consumption concentrated on screens and the alternation with paper and the antenna. The Generation-Z Young people between 16 and 23 years of age who prioritize their consumption through audiovisual components on the Internet), Millennials (subjects between 38 and 56 years old whose media consumption is concentrated in the antenna (radio and television) and the audio-visual elements in the digital ecosystem), $X$ (subjects between 38 and 56 years old whose media consumption is concentrated in the antenna (radio and television) and the audio-visual elements in the digital ecosystem), Baby Boomers (adults aged 57 or over with consolidated traditional media consumption and who timidly approach digital proposals.) In [7], the authors' approach establishes, in a particular way, a letter of communication alternatives that covers print, radio, television, literature, streaming, podcast, video and games [26]; analogical and digital contiguity that, regardless of age, concentrates the tactical impact on social networks.

The health crisis consolidated the audiovisual culture [1], as an instrument of commun ication-YouTube, Instagram, Facebook-through online videos, accentuated at an unexpected speed. Consumption habits, basic needs of Colombian followers, are assumed by the journalistic industry with the adaptation and reevaluation of productive routines. The new reality made it necessary to have digital solutions for requests for information and leisure [10], while providing comfort to the follower on the digital platform. The data tracking, monitoring and control component makes new business opportunities visible in response to the demand for audiovisual content at the beginning of the crisis and the return to everyday life. The clear concentration of actions on Twitter cannot be ignored [12]. The written phenomenon of communication resembles the telegram, an informative speech bubble that leads the interest to delve into the content on the web-medium, but at the same time it leaves the user informed with the headline.

The audience's need for information allows the number of monthly messages to be correlated with the advance of the pandemic in the world and its repercussions in the Colombian territory. It is important to point out the impact of Holy Week in April, which decreases the sending and answering of messages, as can be seen in Table 6. The evocation of the synchronous broadcast is materialized in a social publication for asynchronous consumption [1], a scenario in which the power of the image, fixed and in motion, is more successful than the written text. Posts or tweets are part of the user's conversation with family and friends through text messages, e-mail communications and electronic replies on social platforms [3]. The presence of the media in the digital ecosystem raises the rating, incidence and influence of the brand on particular issues. News agents establish an operational strategy that allows them to capture the attention of the public among thousands of competitors.

The production routine operates according to the behavior of media agents and digital followers. It is evident that they adapt to the logic of the @ generation, provide information and respond to what the user is interested in and looks for [7]. Journalistic deployment allows the creation and strengthening of niches or communities with particular interests; a 
digital focus that strategically facilitates the promotion of initiatives quickly and encourages the opinion and extension of the message by users [24]. On social platforms, the day's news agenda takes on a life of its own and relevance, through Gifs and creative content, the evolution of the news event is tracked. The communication tactic denoted, in the quantitative and qualitative analysis, actions focused in two directions: the needs of the users and the objectives of the media brand.

The triangulation of the data allows us to appreciate the effort of the media to build a story that covers each of the 7 technological devices that the subject has connected to the network on average-Smartphone, TV, tablet, PC, laptop, digital clock, other [23]. The incorporation of technology in the description of events is observed; the architecture of reality from the audiovisual components that testifies the what, how and why of the events that are daily news. The media narrative responds to five biospheres of the digital relationship: alerts, written texts, podcasts, videos and comments [8]. The operational tactic shows a brand personality in which $80 \%$ is strategy and $20 \%$ technology. Connectivity builds public opinion from the communication industry and its relationship with the environment [48], reinvention of languages to say and tell information in another way, while expressing the editorial position of the medium and the journalist in the face of the fact that is transmitted.

\subsection{Social Construction of Reality through the Informative Story}

The technological transformation and innovation process of the media was accelerated by the lockdown and the demand for information by an audience with consumer actions concentrated on screen devices [5]. The speed of events, added to production difficulties and mobility restrictions, evidenced, in the study period, a journalistic work of little depth, context and reality. The production routines are adjusted to the creation of a large virtual support network, a community of friends and regular contacts in different areas of interest: public and private health, politics, official communications and government agent portals [65].

The pandemic outlined a transformation of the conception of the world, understanding and recognition of isolated social sectors. The SARS-CoV-2 environment heightened the understanding of a somewhat complex social fabric due to its organization and the reconfiguration of institutions, roles and practices of knowledge and power. Subjectivities of the social collective show interpretations or needs from the collective intelligence: an increase in the cognitive capacities of people and groups, of perception, of memory, of the possibilities of reasoning, learning and creation. The social scenario requires the media to create processes and actions that address the day-to-day problems of lockdown, learning contexts that propose a rethinking of the immediate action of the mass media and the communication strategies used in the digital ecosystem [14].

The consolidation of the digital environment has become a global and irreversible reality, and for the media industry it not only involves a process of transformation but, above all, of continuous learning [1]. Technological innovation has imposed new forms of consumption whose logics no longer correspond to the analogical system of production, distribution and commercialization of information and entertainment. The normalization of connectivity, ubiquity, timelessness and interactivity constitute values which today are inherent in the content broadcasted by the media, which need to update almost daily the knowledge about the tastes and interests of a multi-device, multi-tasking and multidemand audience [3]. The production, circulation and appropriation of communicative products, by the mass media requires having as a base the four pillars of the knowledge society: access, information for all, freedom of expression and linguistic diversity.

The new action model of the media-press, radio and television-requires mastering languages, narratives and platforms in which content is exposed, but at the same time interacts with the public [31]. The qualitative analysis of the interactions between the sender and the receivers, in this research, shows that the followers of the medium, the brand or the journalist show that the obligation is not to tell stories but rather to put 
these news items into context, clarifying the meanings and implications for the users. The social construction of reality is articulated by an informative agenda consistent with the expansion of programming grids, reformulation of the way of broadcasting information from one place to another, through different platforms, thus configuring a new information ecosystem that integrates new formats, narratives, languages and stories. We are at the forefront of a reinvention of the media industry that finds new ways to tell people what is happening beyond their homes. The unforeseen consequences and unpredictable results of this pandemic, added to the urgency of knowing third-hand information and carrying out aggregation journalism, was what led to, on some occasions, for decontextualized information to circulate very easily [22].

The results of this research show how the media industry has assumed the demands imposed by the new consumer environment and what strategies are now conditioning its activity. Push notification alerts on mobiles constitute new ways of microjournalism in which the proximity of the media to the daily routines of users is strengthened: breaking news, appeals to live consumption or to consult content on the web, sports results, exclusive topics, supplementary data. The loss of relevance and hallmark that the media had prior to the pandemic is reversed during the lockdown [65]. The spaces for the circulation of information and opinion are now open to the participation and direct interaction of millions of users who, de facto, become potential media. The challenge for the media industry is to configure a coordinated convergent broadcast system-paper, antenna, screen and networks - to define new professional profiles-social media, big data, designnew metrics—audio, video, social networks — and, above all, a new mentality: the digital environment imposes innovation, and the media no longer represents a synonym for storytelling, but for dialog with its increasingly atomized audiences.

\section{Conclusions}

The Colombian media industry continues to be a reference of information for all audiences. The traditional medium is the production axis for the news brand that has assumed the demands imposed by the new consumer environment of an audience concentrated on screen devices. The SARS-CoV-2 conjuncture reinvigorated the role of mass media as constructors of reality and the meeting point where the nation's news agenda is discussed. The young levels of the population showed that, due to family tradition or consumer reference, the press, radio and television have a name and a consolidated image, a benchmark of credibility, which is sought in the digital ecosystem.

Analysis of the corpus of study shows that, in the midst of confinement, the sending agents managed operational strategies in response to digital disruption, multiplicity of offline and online communication proposals that converge to inform older audiences, already captivated, and position themselves as a consumer option in the country's young audiences. Triangulation of analysis factors warn that the media industry maintains a strong control over the process and the result of the communication, as it allows access to the material, encourages the participation of the audience, but always under the interests of the news agency. The panorama of the relationship between the medium and its users is linked not only to the communication product but also to social networks, a scenario in which messages inform while self-promoting the medium to gain followers on the social network and become a current point of reference.

Users, when connected to the network, concentrate their consumption time on the search for information and on building their notion of reality from the audiovisual products that are shared. The active role of the followers is concentrated on reaction buttons, sharing the most interesting posts, memes and comments and interactions between other followers. Conversation with journalists and the proposal of topics, or other approaches to the news, still appear to be activities of lesser importance. Audience behavior confirms that the conventional media preserve their informational status and news monitoring habits, likewise, that in order to gain followers in the digital field, reinforcement communication strategies 
must be promoted on the web, social networks and musical sharing platform, likewise, to promote a strategy that goes beyond the marketing proposed by the media industry.

The vision of a particular issue such as lockdown and everything that the SARS-CoV-2 brought with it is structured from an administrative tactic by the news company that favors the broadcasting of the media mix (Figure 8) associated with ideas of communication 4.0. The contents are collectivized and shared in an open way to provide meanings and signifiers that allow users to build the notion of the reality of the social fabric in which they operate. The corpus of study denotes a new way of narrating the facts, giving an assertive response to the paradigm of the needs and consumption habits of today's society to ensure the presence and consumption of the business brand in various settings. From trial and error, we seek to determine the most successful strategy to guide the user to a complementary consumption under a $360^{\circ}$ strategy in each of the scenarios where the brand of the medium is present.
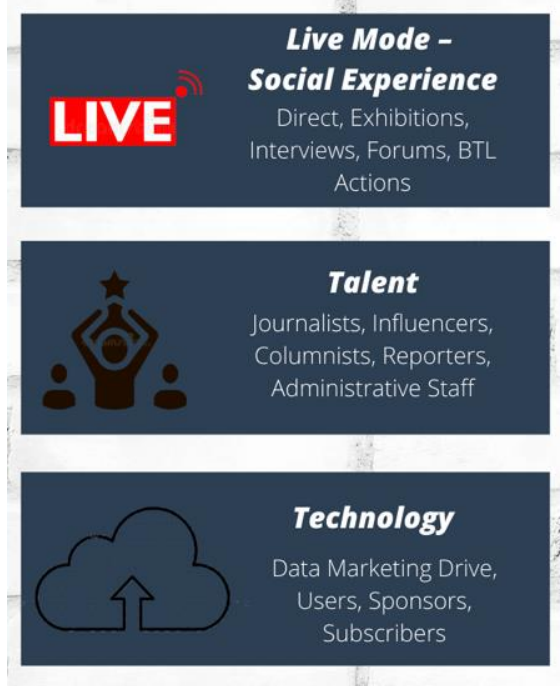
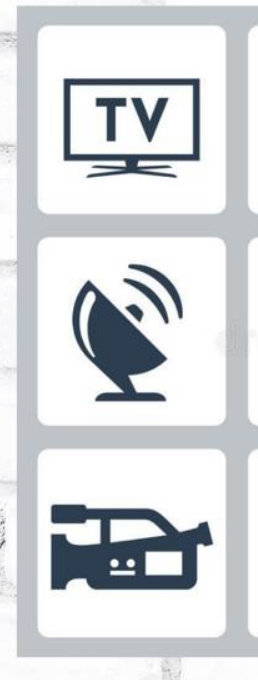
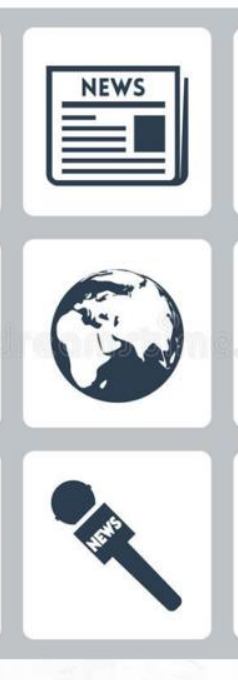
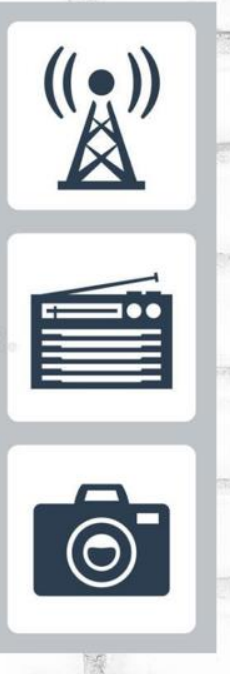
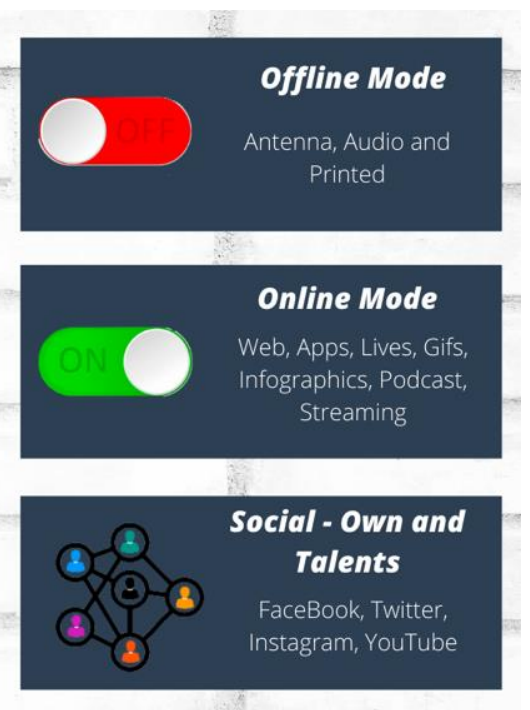

Figure 8. Convergence of approaches to the media content. Prepared by author.

The media industry must understand that the impact rates, at this juncture, will be maintained over time if the construction and strengthening of a community with particular interests continues. The digital ecosystem fosters channels to search and distribute information, receive feedback, follow up on news events, flag and promote initiatives quickly, and maintain constant communication to motivate opinion and construction, together, of the stories that take place in the conventional medium. In spite of the infodemic and information overload that surrounded the media biosphere, during the lockdown, the press, radio and television focused on validating and bringing awareness campaigns back on trend based on empathetic tones that respond to the introspective turn and human urgency that the crisis plunged into a national collective.

The information company as a provider of information and entertainment explored, during the lockdown, how to capture the attention of the various audiences on the network, establish follow-up links, greater than the existing ones, to be a meeting point where relationships of identification, complicity, and union are established. The data of a particular ecosystem, in this case the Colombian one, must be contextualized and contrasted with particular scenarios in other countries to determine to what extent these affect the link of the audience with the news media. This work should be considered as an exploratory input that should serve to generate more questions about how the media industry is revitalized and promotes the consumption of content. At the end of this crisis, we must ask ourselves: will the mass media remain the same after this pandemic? 
Funding: This research received no external funding.

Institutional Review Board Statement: Not applicable.

Informed Consent Statement: Not applicable.

Data Availability Statement: The data are not available in a public place.

Conflicts of Interest: The authors declare no conflict of interest.

\section{References}

1. Montaña Blasco, M.; Ollé Castellà, C.; Lavilla Raso, M. Impacto de la pandemia de COVID-19 en el consumo de medios en España. Rev. Lat. Comun. Soc. 2020, 78, 155-167. [CrossRef]

2. Rodero, E. Radio: The medium that best copes in crises. Listening habits, consumption, and perception of radio listeners during the lockdown by the COVID-19. Prof. Inf. 2020, 29. [CrossRef]

3. Barrios-Rubio, A.; Pedrero-Esteban, L.M. The Transformation of the Colombian Media Industry in the Smartphone Era. J. Creat. Commun. 2021, 16, 45-60. [CrossRef]

4. Casero-Ripollés, A.; García-Gordillo, M. La influencia del Periodismo en el ecosistema digital. In Cartografía de la Comunicación Postdigital: Medios y Audiencias en la Sociedad de la COVID-19; Pedrero-Esteban, L.M., Pérez-Escoda, A., Eds.; Thomson Reuters: Toronto, ON, Canada, 2020; pp. 157-176.

5. Lázaro-Rodríguez, P.; Herrera-Viedma, E. Noticias sobre COVID-19 y 2019-nCoV en medios de comunicación de España: El papel de los medios digitales en tiempos de confinamiento. Prof. Inf. 2020, 29, e290302. [CrossRef]

6. Mullo-López, A.; de-Casas-Moreno, P.; Balseca-Mera, J.M. Tratamiento informativo y competencias mediáticas sobre la COVID-19 en Ecuador. Rev. Comun. 2021, 20, 137-152. [CrossRef]

7. Barrios-Rubio, A. Radio, music and podcast in the consumption agenda of Colombian adolescents and youth in the digital sonosphere. Commun. Soc. 2021, 34, 31-46. [CrossRef]

8. Pedrero-Esteban, L.M.; Barrios-Rubio, A.; Medina-Ávila, V. Teenagers, smartphones and digital audio consumption in the age of Spotify. Comun. Media Educ. Res. J. 2019, 60, 103-112. [CrossRef]

9. Lang, B.; Dolan, R.; Kemper, J.; Northey, G. Prosumers in times of crisis: Definition, archetypes and implications. J. Serv. Manag. 2021, 32, 176-189. [CrossRef]

10. Lázaro-Rodríguez, P. COVID-19, medios digitales y Facebook: Interacciones, tratamiento y análisis de contenido basado en palabras clave de noticias de okdiario.com y eldiario.es. Prof. Inf. 2020, 29. [CrossRef]

11. Torres-Romay, E.; García Mirón, S. Influencers y coronavirus. Los contenidos sobre la pandemia COVID-19 en las publicaciones de prescriptores de redes sociales en España (2020): El caso de Instagram. Quad. CAC 2020, XXIII, 81-91.

12. Mourad, A.; Srour, A.; Harmanai, H.; Jenainati, C.; Arafeh, M. Critical Impact of Social Networks Infodemic on Defeating Coronavirus COVID-19 Pandemic: Twitter-Based Study and Research Directions. IEEE Trans. Netw. Serv. Manag. 2020, 17, 2145-2155. [CrossRef]

13. Soengas-Pérez, X.; López-Cepeda, A.; Sixto-García, J. Dieta mediática, hábitos de consumo de noticias y desinformación en los universitarios españoles. Rev. Lat. Comun. Soc. 2019, 74, 1056-1070. [CrossRef]

14. Cinelli, M.; Quattrociocchi, W.; Galeazzi, A.; Valensise, C.M.; Brugnoli, E.; Schmidt, A.L.; Zola, P.; Zollo, F.; Scala, A. The COVID-19 social media infodemic. Sci. Rep. 2020, 10, 16598. [CrossRef] [PubMed]

15. Barrios-Rubio, A. From the Antenna to the Display Devices: Transformation of the Colombian radio Industry. J. Media 2021, 2, 208-224. [CrossRef]

16. Scolari, C.A.; Establés, M.J. Ecología mediática en tiempos de pandemia: Virus, comunicación e interfaces. In Cartografía de la Comunicación Postdigital: Medios y Audiencias en la Sociedad de la COVID-19; Pedrero-Esteban, L.M., Pérez-Escoda, A., Eds.; Thomson Reuters: Toronto, ON, Canada, 2020; pp. 57-72.

17. Jenkins, $\mathrm{H}$. El media fandom como recurso de alfabetización en la sociedad red. In Cartografía de la Comunicación Postdigital: Medios y Audiencias en la Sociedad de la COVID-19; Pedrero-Esteban, L.M., Pérez-Escoda, A., Eds.; Thomson Reuters: Toronto, ON, Canada, 2020; pp. 73-95.

18. Costa-Sánchez, C.; López-García, X. Comunicación y crisis del coronavirus en España. Primeras lecciones. Prof. Inf. 2020, 29, e290304. [CrossRef]

19. Martínez-Costa, M.P. Radio y nuevas narrativas: De la crossradio a la transradio. In Radio, Sound and Internet Proceedings of Net Station International Conference; Oliveira, M., Ribeiro, F., Eds.; Universidad do Minho: Minho, Portugal, 2015 ; pp. 168-187.

20. Orozco-Gómez, G. La Múltiple Audienciación de las Sociedades Contemporáneas: Desafíos para su Investigación. Anu. Electrónico Estud. Comun. Soc. Disert. 2018, 11, 13-25. [CrossRef]

21. Aleixandre-Benavent, R.; Castelló-Cogollos, L.; Valderrama-Zurián, J.C. Información y comunicación durante los primeros meses de COVID-19. Infodemia, desinformación y papel de los profesionales de la información. Prof. Inf. 2020, 29, e290408. [CrossRef]

22. García-Marín, D. Infodemia global. Desórdenes informativos, narrativas fake y fact-checking en la crisis de la COVID-19. Prof. Inf. 2020, 29. [CrossRef]

23. Hootsuite. Digital 2020 Colombia. 2020. Available online: https://datareportal.com/reports/digital-2020-colombia (accessed on 2 December 2021). 
24. Sádaba, C.; Pérez-Escoda, A. La generación streaming y el nuevo paradigma de la comunicación digital. In Cartografía de la Comunicación Postdigital: Medios y Audiencias en la Sociedad de la COVID-19; Pedrero-Esteban, L.M., Pérez-Escoda, A., Eds.; Thomson Reuters: Toronto, ON, Canada, 2020; pp. 97-114.

25. Gil-Torres, A.; Martín-Quevedo, J.; Gómez-García, S.; San José-De la Rosa, C. El coronavirus en el ecosistema de los dispositivos móviles: Creadores, discursos y recepción. Rev. Lat. Comun. Soc. 2020, 78, 329-358. [CrossRef]

26. Pérez Tornero, J.M.; Pedrero Esteban, L.M. Las coordenadas digitales del ecosistema comunicativo. In Cartografía de la Comunicación Postdigital: Medios y Audiencias en la Sociedad de la COVID-19; Pedrero-Esteban, L.M., Pérez-Escoda, A., Eds.; Thomson Reuters: Toronto, ON, Canada, 2020; pp. 37-56.

27. Aguado, J.M. Mediaciones Ubicuas. Ecosistema Móvil, Gestión de Identidad y Nuevo Espacio Público; Gedisa: Barcelona, Spain, 2020.

28. Romero-Rodríguez, L.M.; Tejedor, S. De la inmediatez de los cibermedios a la profundidad del Slow Journalism. In Cartografía de la comunicación postdigital: Medios y audiencias en la Sociedad de la COVID-19; Pedrero-Esteban, L.M., Pérez-Escoda, A., Eds.; Thomson Reuters: Toronto, ON, Canada, 2020; pp. 255-279.

29. Larrondo Ureta, A.; López García, X. A resignificación de la convergencia mediática en el periodismo hi-tech. In Cartografía de la Comunicación Postdigital: Medios y Audiencias en la Sociedad de la COVID-19; Pedrero-Esteban, L.M., Pérez-Escoda, A., Eds.; Thomson Reuters: Toronto, ON, Canada, 2020; pp. 137-156.

30. Aitamurto, T. Normative paradoxes in $360^{\circ}$ journalism: Contested accuracy and objectivity. New Media Soc. 2019, 21, 3-19. [CrossRef]

31. García-Avilés, J.A.; Herrera Damas, S. Panorama de los formatos narrativos innovadores en el periodismo digital. In Cartografía de la Comunicación Postdigital: Medios y Audiencias en la Sociedad de la COVID-19; Pedrero-Esteban, L.M., Pérez-Escoda, A., Eds.; Thomson Reuters: Toronto, ON, Canada, 2020; pp. 225-253.

32. Lee, K. AI Superpowers. China, Silicon Valley and the New World Order; Houghton Mifflin Harcourt: Boston, MA, USA, 2018.

33. Gutiérrez-García, M.; Barrios-Rubio, A. Del offline a la r@dio: Las experiencias de la industria radiofónica española y colombiana. Rev. Comun. 2019, 18, 73-94. [CrossRef]

34. Fletcher, R.; Cornia, A.; Nielsen, R.K. How polarized are online and offline news audiences? A comparative analysis of twelve countries. Int. J. Press/Politics 2020, 25, 169-195. [CrossRef]

35. Riskos, K.; Hatzithomas, L.; Dekoulou, P.; Tsourvakas, G. The influence of entertainment, utility and pass time on consumer brand engagement for news media brands: A mediation model. J. Media Bus. Stud. 2021, 1-28. [CrossRef]

36. Cervi, L.; Simelio, N.; Tejedor, S. Analysis of Journalism and Communication Studies in Europe's Top Ranked Universities: Competencies, Aims and Courses. Journal. Pract. 2020. [CrossRef]

37. Asociación Colombiana de Investigación de Medios Estudio General de Medios en Cuarentena. 2020. Available online: http: //www.acimcolombia.com/boletines/presentamos-el-egm-cuarentena/ (accessed on 2 December 2021).

38. Comscore. Principales Tendencias Digitales en Colombia al 1T 2021. 2021. Available online: https://www.comscore.com/lat/ Prensa-y-Eventos/Blog/Principales-tendencias-digitales-en-Colombia-al-1T-2021 (accessed on 2 December 2021).

39. Barrios-Rubio, A. La Radio Generalista Colombiana Ante el Desafío Digital: Un modelo en Transición. Ph.D. Thesis, Universitat Autònoma de Barcelona, Catalonia, Spain, 2016. Available online: https://ddd.uab.cat/record/167870 (accessed on 2 December 2021).

40. Ardèvol, E.; Bertrán, M.; Callén, B.; Pérez, C. Etnografía virtualizada: La observación participante y la entrevista semiestructurada en línea. Athenea Digit. Rev. Pensam. Investig. Soc. 2003, 3, 72-92.

41. Habann, F. Towards a Methodological Foundation of Media Innovation Reserarch. In Management and Innovation in the Media Industry; Zotto, C.D., Van-Kranenburg, H., Eds.; Edward Elgar Publishing: Cheltenham, UK, 2008; pp. 67-86.

42. Krumsvik, A.; Storsul, T. (Eds.) Media Innovations: A Multidisciplinary Study of Change; Nordicom: Gotemburgo, Sweden, 2013.

43. Holsti, O. Content Analysis for the Social Sciences and Humanities; Longman Higher Education: New York, NY, USA, 1969.

44. Wimmer, R.; Dominick, J. La Investigación Científica de los Medios de Comunicación. Una Introducción a Sus Métodos; Bosch: Geilingen, Germany, 1996.

45. Díaz, C.M. ¿Cómo desarrollar, de una manera comprensiva, el análisis cualitativo de los datos? Educere 2009, $13,55-66$.

46. Ortega, F.; Galhardi, C. Propuesta Metodológica para el análisis de contenido de la parrilla de Televisión en Brasil: Análisis de un caso práctico en los estados de São Paulo, Rio Grande do Sul, Estado da Bahía. In Actas $2^{\circ}$ Congreso Nacional Sobre Metodología de la Investigación en Comunicación: Investigar la Comunicación hoy. Revisión de Políticas Científicas y Aportaciones Metodológicas; Universidad de Valladolid: Valladolid, Spain, 2013; Available online: http:/ / uvadoc.uva.es/handle/10324/3038 (accessed on 2 December 2021).

47. Martínez-Rodrigo, E.; Sánchez-Martín, L. Comunicación y Redes Sociales Presentación. ICONO 14 Rev. Comun. Tecnol. Emerg. 2015, 13, 1-5. [CrossRef]

48. Terán-Villegas, O.R.; Aguilar-Castro, J.L. Modelo del proceso de influencia de los medios de comunicación social en la opinión pública. Educere 2018, 22, 179-191.

49. Peña-Fernández, S.; Lazkano-Arrillaga, I.; Larrondo-Ureta, A. Medios de comunicación e innovación social. El auge de las audiencias activas en el entorno digital. Andamios 2019, 16, 351-372. [CrossRef]

50. Gutiérrez-Cortés, F.; Islas-Carmona, O.; Arribas-Urrutia, A. Las nuevas leyes de los nuevos medios y la reconfiguración del entorno. Palabra Clave 2019, 22, 22-29. [CrossRef] 
51. Barrios-Rubio, A.; Gutiérrez-García, M. Reconfiguración de las dinámicas de la industria radiofónica colombiana en el ecosistema digital. Cuadernos. Info. 2017, 41, 227-243. [CrossRef]

52. Negredo, S.; Martínez-Costa, M.P.; Breiner, J.; Salaverría, R. Journalism Expands in Spite of the Crisis: Digital-Native News Media in Spain. Media Commun. 2020, 8, 73-85. [CrossRef]

53. Salaverría, R.; Sádaba, C.; Breiner, J.; Warner, J. A Brave New Digital Journalism in Latin America. In Communication: Innovation E Quality. Studies in Systems, Decision and Control; Túñez-López, M., Martínez-Fernández, V.A., López-García, X., Rúas-Araújo, X., Campos-Freire, F., Eds.; Springer Publishing: Cham, Switzerland, 2019; pp. 229-247. [CrossRef]

54. Mayoral, J.; Edo, C. Tipología de vídeos en el periodismo digital español: Análisis cualitativo de cinco cibermedios. Doxa Comun. 2014, 1921-1956. [CrossRef]

55. Silverman, D. Doing Qualitative Research; SAGE Publishing: Southend Oaks, CA, USA, 2013.

56. Tsujimoto, M.; Yuya, K.; Junichi, T.; Yoichi, M. A review of the ecosystem concept-Towards coherent ecosystem design. Technol. Forecast. Soc. Change 2018, 136, 49-58. [CrossRef]

57. Bernal, C. Metodología de la Investigación, 3rd ed.; Pearson Educación: Bogotá, Colombia, 2010.

58. Bonilla, E.; Rodríguez, P. Más Allá del Dilema de los Métodos; Grupo Editorial Norma: Bogotá, Colombia, 2005.

59. Salazar-Gómez, M.; Sepúlveda, R. Perspectivas y proyección profesional de la comunicación social. Rev. Signo Pensam. 2011, LIX, 194-209.

60. López-Vidales, N. Medios de Comunicación, Tecnología y Entretenimiento: Un Futuro Conectado; Editorial Laertes: Barcelona, Spain, 2008.

61. Cabrera, M.Á. La interactividad de las audiencias en entornos de convergencia digital. Rev. ICONO14-Rev. Científica Comun. Tecnol. Emerg. 2010, 8, 164-177. [CrossRef]

62. García, J.A. La comunicación ante la convergencia digital: Algunas fortalezas y debilidades. Signo Pensam. 2009, XXVIII, 102-113.

63. Nielsen, R.K.; Fletcher, R.; Newman, N.; Brennen, J.S.; Howard, P.N. Navigating the 'Infodemic': How People in Six Countries Access and Rate News and Information about Coronavirus; Reuters Institute for the Study of Journalism, University of Oxford: Oxford, UK, 2020.

64. Barrios-Rubio, A.; Gutiérrez-García, M. Migration of the Colombian radio strategy: From sound to social screens. Rev. Lat. Comun. Soc. 2016, 71, 1243-1260. [CrossRef]

65. Casero-Ripollés, A. Impact of COVID-19 on the media system. Communicative and democratic consequences of news consumption during the outbreak. Prof. Inf. 2020, 29, e290223. [CrossRef] 